\title{
CHEST WALL TUBERCULOSIS: A SURGICAL OR A MEDICAL ENTITY
}

\author{
Roghieh Golsha ${ }^{1}$, Mahin Jamshidi Makiani ${ }^{2}$, Katayonn Rahmdel ${ }^{3}$, Abddollah Abbasi ${ }^{1}$
}

1: M.D., Associate Professor of Infectious Disease, Research Center of Infectious Disease, Golestan University of Medical Sciences Gorgan, Iran

2: M.D., Associate Professor of Infectious Disease, Anti-Microbial Resistant Research Center, Infectious Department, Iran University of Medical Sciences Tehran, Iran

3: M.D., Thoracic Surgery Specialist, Research Center of Infectious Disease, Golestan University of Medical Sciences Gorgan, Iran

\section{TYPE OF ARTICLE: ORIGINAL ARTICLE}

\begin{abstract}
Introduction: Extrapulmonary tuberculosis (TB) constitutes $15 \%-20 \%$ of TB cases. Chest wall TB is a common cause of destructive rib lesions and often diagnosed with delay. Recurrence rate following medical treatment as a single mode of therapy is high. The aim of this study was to assess the approach to chest wall tuberculosis in six cases presenting with a chest wall mass or fistula in the northeast of Iran during a three-year period.

Methods: This case series was carried out during a period of three years, between 2003 and 2006. Diagnosis of chest wall TB was established by the symptoms and signs of the patients, previous history of TB, location of the chest wall lesion, the results of aspirates, chest x-rays, biopsy and culture results, and computed topography (CT) scan of the lung. The effects of anti-TB regimens and surgery as parts of diagnosis or treatment were noticed.

Results: Among the patients, $83.3 \%$ were originally from the southeast region of Iran. There was a positive history of lung TB in $33.3 \%$ of cases, one having concomitant active lung TB under a four-drug anti-TB therapy. A cold abscess in $50 \%$ and a chest wall fistula in $16.6 \%$ of cases were the presenting signs and symptoms. All results of the aspirates for acid-fast bacilli (AFB) smear were negative. Culture result was positive only in one patient after 40 days. The definite diagnosis was based on the pathologic results of the surgical biopsy in all cases.
\end{abstract}

Conclusion: Surgery is the crucial part of diagnosis and treatment in cases of chest wall tuberculosis and should be accompanied by a period of treatment through anti-TB drugs.

KEYWORDS: Tuberculosis, Chest wall, Surgery, Acid-fast bacilli smear

\section{INTRODUCTION}

Although the incidence of tuberculosis (TB) has shown a decline with using effective anti-TB drugs, it is still high in developing countries (1). Whereas the lungs are the main target in primary infection, extrapulmonary TB has been reported to constitute one-fourth to half of all TB cases in some studies (2-4). Chest wall TB is a rare entity, and its clinical presentation may resemble a pyogenic abscess or a chest wall mass (1). As a cause of destructive rib lesions, TB is the second differential diagnosis after metastatic malignancies (5). In a series of skeletal TB, the ribs have been involved in $7 \%$ of patients (6). TB of chest wall constitutes $1 \%-5 \%$ of all musculoskeletal TB cases $(7,8)$. Rib TB is often faced with a delay in diagnosis, and it usually recurs even after medical treatment (7). The reasons for misdiagnosis or the delay include vague symptoms, various radiological features, and the frequent failure of smears or cultures of aspirates in showing tubercle bacilli $(7,8)$. Diagnosis can be made with a diagnostic aspiration of the abscess. Anti-TB therapy must be continued for six to nine months, surgical debridement is reserved for failures (9). The role of surgery in the diagnosis and treatment of chest wall TB is still controversial (1). Incision and drainage of abscess as the single modes of therapy do not lead to recovery and will result in fistula formation (10). This study

\section{Correspondence:}

Dr. Katayonn Rahmdel, Research Center of Infectious Diseases, Golestan University of Medical Sciences, Gorgan, Iran. Tel: +98.9121595893, E-mail: K_rahmdel@yahoo.com

Received: September 14, 2016, Accepted: October 23, 2016, Published: December 2016

iThenticate screening: September 16, 2016, English editing: October 30, 2016, Quality control: November 7, 2016

(C) 2016 The Authors. This is an open access article under the terms of the Creative Commons Attribution-NonCommercialNoDerivs License, which permits use and distribution in any medium, provided the original work is properly cited, the use is non-commercial and no modifications or adaptations are made. 
shows our experience in six patients with chest wall TB and considers the clinical presentation, diagnostic workup, and the role of surgery in diagnosis and management of the disease.

\section{MATERIAL AND METHODS}

\subsection{Research design and setting}

This case series was carried out in Gorgan on six patients with chest wall TB. During a three-year period (20032006), six cases with chest wall TB were managed in Gorgan, in northern Iran.

\subsection{Data collection}

We considered epidemiologic characteristics, clinical presentation, diagnostic workup, treatment strategies, and the results of medical and surgical treatment in the present study. For the diagnostic approach, we considered the symptoms and signs of the patients, location of the chest wall mass, the aspiration results of the chest wall abscess, chest X-rays, biopsy and culture results, and CT scans of the lung. The chest wall mass was at the first presentation, and aspiration was the first diagnostic approach. Microbiological and cytological studies and acid-fast bacilli (AFB) testing were conducted on the aspirated fluid. No tissue biopsy was performed at the initial aspiration. In the case of patients with non-diagnostic aspiration, an operative approach was taken as follows: drainage of the pus, excision of the abscess wall, abnormal-looking surrounding tissues, the fistula tract if presents and involved ribs or a sequestrum. Diagnostic criteria were based on one or more of the following: the presence of granulomatous with caseous necrosis in the specimen and positive results for AFB (Zhiel-Neelson staining (smear) or LowensteinJensen medium).

\subsection{Research ethics}

The research proposal was confirmed by the Ethics Committee of the Hormozgan University of Medical Sciences. Written informed consent was obtained from each patient after explanation of the study protocol.

\section{RESULTS}

All of the patients except one were originally from Sistan-Baluchestan, a province in the southeast of Iran bordering Pakistan, with ages ranging from 24 to 78 years and a mean age of 40 years. Four of the patients were male.

$33.3 \%$ of the patients had a previous history of TB, one of them concomitantly having active pulmonary TB under a four-drug regimen of anti-TB chemotherapy. The cold abscess and fistula formation were found in $50 \%$ and $16.6 \%$ of the cases, respectively. Chest wall mass in 50\% had a firm consistency, so aspiration was not done, but, in the rest, the chest wall mass was soft and fluctuating on physical examination (Table 1) with negative results of aspiration for AFB smears. After 40 days, culture was positive in $16.6 \%$ of cases. The radiological findings were not completely diagnostic, only $33.3 \%$ had rib erosion and mediastinal lymphadenopathy. Half of the cases had rim calcification, necrosis, and parenchymal complications (Table 2). Solitary and multiple rib involvement were found in $33.3 \%$ of cases. The surgical approach included resection of the mass, involved ribs, the sequestrum, surrounding soft tissues necrotized, fistula tract, and abscess wall. Following the extensive debridement procedures, the wound was dressed. In all patients, findings were diagnostic of TB (Table 2). During the waiting period for diagnostic practices, $50 \%$ of patients using anti-TB regimen developed two or three more chest wall masses. After the surgical debridement, anti-TB regimen was used for six months. At the three-year follow-up, no evidence of recurrence of disease or post-surgical fistula was seen in our patients.

Table 1. Clinical Presentation and Identification Data of Patients with Chest Wall TB

\begin{tabular}{|c|c|c|c|c|c|c|c|c|}
\hline $\begin{array}{l}\text { Case } \\
\text { No } \\
\end{array}$ & $\begin{array}{l}\text { Age } \\
(\mathrm{y} / \mathrm{o})\end{array}$ & $\begin{array}{l}\text { Sex } \\
(\mathrm{M} / \mathrm{F}) \\
\end{array}$ & $\begin{array}{l}\text { Chest Location } \\
\text { of Mass }\end{array}$ & $\begin{array}{l}\text { Local } \\
\text { Tenderness }\end{array}$ & $\begin{array}{l}\text { Local } \\
\text { Pain }\end{array}$ & $\begin{array}{l}\text { Local } \\
\text { Erythema }\end{array}$ & $\begin{array}{l}\text { Diameter } \\
(\mathrm{cm})\end{array}$ & $\begin{array}{l}\text { Duration } \\
\text { (month) }\end{array}$ \\
\hline 1 & 78 & $\mathrm{M}$ & Rt upper lat & - & - & - & $4 \times 7$ & 6 \\
\hline 2 & 26 & $\mathrm{~F}$ & $\mathrm{Lt}$, parasternal & + & + & + & $3 \times 3$ & 3 \\
\hline 3 & 70 & $\mathrm{M}$ & Rt midclavicular & - & + & - & $5 \times 4$ & 1 \\
\hline 4 & 18 & $\mathrm{~F}$ & Lt parasternal & + & + & - & $2 \times 2$ & 4 \\
\hline 5 & 55 & $\mathrm{M}$ & Rt anterior & - & + & - & $6 \times 2$ & 7 \\
\hline 6 & 2 & $\mathrm{~F}$ & Rt lower anterior & + & + & + & $1.5 \times 2$ & 4 \\
\hline
\end{tabular}


Table 2. Diagnostic Work-up in Patients with Chest Wall Tuberculosis

\begin{tabular}{|c|c|c|c|c|c|c|}
\hline \multirow{2}{*}{$\begin{array}{l}\text { Case } \\
\text { no }\end{array}$} & \multirow[t]{2}{*}{ Type of lesion } & \multicolumn{2}{|c|}{ Initial aspirate } & \multicolumn{2}{|l|}{ Radiology } & \multirow{2}{*}{$\begin{array}{l}\text { Debridement } \\
\text { Specimen } \\
\text { Histology }\end{array}$} \\
\hline & & AFB & Culture & Chest X-ray & $\begin{array}{l}\text { Computed } \\
\text { Tumography }\end{array}$ & \\
\hline 1 & $\begin{array}{l}\text { Firm chest wall } \\
\text { mass }\end{array}$ & $\begin{array}{l}\text { Not } \\
\text { tested }\end{array}$ & $\begin{array}{l}\text { Not } \\
\text { tested }\end{array}$ & Rim calcification & $\begin{array}{l}\text { Rim calcification and } \\
\text { necrosis, rib erosion }\end{array}$ & CGN,LGC \\
\hline 2 & $\begin{array}{l}\text { Multiple chest wall } \\
\text { cold abscess }\end{array}$ & - & + & $\begin{array}{l}\text { Parenchymal } \\
\text { calcification, } \\
\text { Hilar adenopathy }\end{array}$ & $\begin{array}{l}\text { Rim calcification and } \\
\text { necrosis, rib erosion, } \\
\text { parenchymal and } \\
\text { pleural involvement }\end{array}$ & CGN \\
\hline 3 & $\begin{array}{l}\text { Multiple } \\
\text { inflammatory mass } \\
\text { under four-drug } \\
\text { anti-TB treatment }\end{array}$ & - & - & $\begin{array}{l}\text { Parenchymal } \\
\text { involvement }+ \\
\text { calcification }\end{array}$ & $\begin{array}{l}\text { Hilar adenopathy }+ \\
\text { calcificatio, } \\
\text { parenchymal and } \\
\text { pleural involvement }\end{array}$ & CGN,LGC \\
\hline 4 & $\begin{array}{l}\text { Firm chest wall } \\
\text { mass }\end{array}$ & $\begin{array}{l}\text { Not } \\
\text { tested }\end{array}$ & $\begin{array}{l}\text { Not } \\
\text { tested }\end{array}$ & NL & Med LAP & CGN \\
\hline 5 & Fistula formation & - & - & $\begin{array}{l}\text { Nodular chest wall } \\
\text { calcification, old } \\
\text { parenchymal } \\
\text { involvement }\end{array}$ & $\begin{array}{l}\text { Nodular chest wall } \\
\text { calcification, old } \\
\text { parenchymal } \\
\text { involvement, calcified } \\
\text { fistula tract }\end{array}$ & CGN,LGC \\
\hline 6 & $\begin{array}{l}\text { Soft tissue chest } \\
\text { wall mass }\end{array}$ & - & - & NL & Soft tissue swelling & CGN,LGC \\
\hline
\end{tabular}

AFB: Acid Fast Bacilli; (-): negative; (+) positive; Med LAP: Mediastial Lymphadenopathy; NL: Normal;

CGN: Caseous Granulomatous Necrosis; LGC: Langhan's Giant Cell.

\section{DISCUSSION}

Despite great advances, TB still remains one of the diagnostic and therapeutic challenges. TB is endemic in Iran and in the neighboring countries. Globally, it was estimated that there were 9.27 million incident cases of TB in 2007. Most of the estimated cases were in Asia (55\%) and Africa (31\%), and a smaller number of cases in the Eastern Mediterranean region (6\%), the European region (5\%), and the region of the Americas (3\%). Pulmonary involvement is the most common type of TB, but nowadays there is an increase in extra-pulmonary manifestations. Chest wall TB is a rare disease and enrolls in differential diagnosis of chest wall masses. Chest wall TB can present in the forms of painful chest wall mass with or without fluctuation (cold abscess) and/or the fistula formation (11, 12). Chest wall TB may occur by means of two mechanisms:

1) Hematogenous dissemination associated with activation of the dormant foci of tubercle infections (1).

2) Direct extension of the lymphadenitis of the chest wall (12). Burke described the evolution steps of cold abscess of chest wall as follows (13): TB bacilli invade the pleural space and set up a local or a widespread pleuritis; some bacilli are transported to the parasternal or posterior intercostal lymph nodes, and the rupture of these caseous lymph nodes forms a cold abscess in the chest wall (13).

Three of our patients had a soft fluctuating mass (abscess) and two of them a firm mass; in the last remaining patient, a chronic anterior chest wall fistula was found. Lee reported rib destruction in $69 \%$ of cases (14). In our series, the radiologic findings indicated rib involvement in three patients $(50 \%)$. The association of a soft tissue mass with the osteolytic lesion and sequestration suggests the chest wall TB on CT scan of thorax (15). Two (33.3\%) of our patients had a past history of TB and one of them was under a four-drug anti-TB regimen at the time of chest wall TB diagnosis. In Faure's report, $83 \%$ of patients had a history of TB and in $33 \%$ of them, there had been the active pulmonary TB (11). In terms of location, abscesses were parasternal in two patients; other parts of the anterior thoracic wall were involved in four, but posterior thoracic wall was not involved in any case (Table 1). This result is not in conformity with Burke's (13) and Kuzucu's (12) statements about the major localization of the chest wall lesions. In those studies, although draining sinus was reported to have a frequency of $25 \%$, in our study it was found in one patient (16.6\%). In one study, the initial aspiration was diagnostic in only one patient (17\%) (1), but the result of the aspiration smear was negative in all of our cases, and the culture result was only positive in one of them (16.6\%). In review articles, CT scan demonstrates peripherally enlarging chest wall collection, enlarged 
intrathoracic lymph nodes, with the comparatively lesser involvement of the lung parenchyma and pleura (16). The association of a soft tissue abscess, an osteolytic lesion, and a sequestrum suggests chest wall TB on CT scan (15). In our series, radiologic findings showed rib lesions and mediastinal lymphadenopathy in $40 \%$ and rim calcification, necrosis, and parenchymal calcification in 50\%. Due to the fact that neither of the above-mentioned tools (radiology, smears, and cultures) is sufficiently diagnostic for the chest wall TB, the surgical debridement and histopathologic study are recommended to reach a definite diagnosis. Even though surgery has played an undoubtedly full role in the diagnosis of the chest wall TB, its role remains controversial in the treatment of the disease. Some series (8, 17) reported satisfactory results from only the anti-TB therapy, but, in some others, as in our study, abscesses were not cured or they recurred despite intensive anti-TB therapy (12). The surgical intervention in our study was a complete excision of involved tissues including soft tissue nodules, abscess wall, necrotic tissue, adjacent destroyed ribs and internal suppurative lymph nodes. After surgery, all patients underwent a four-drug anti-TB therapy for at least six months with complete improvement and no evidence of recurrence after a three-year follow-up.

\section{CONCLUSIONS}

According to the findings, it seems that surgery is the crucial part of diagnosis and treatment in cases of chest wall tuberculosis and should be accompanied by a period of treatment through anti-TB drugs. We recommend chest wall surgery and anti-TB medications for chest wall TB. More studies are needed to confirm our findings.

\section{ACKNOWLEDGMENTS:}

The authors want to thank Vice Chancellor for Research of Golestan University of Medical Sciences for their help and support.

\section{CONFLICT OF INTEREST:}

There is no conflict of interest to be declared.

\section{AUTHORS' CONTRIBUTIONS:}

All authors contributed to this project and article equally. All authors read and approved the final manuscript.

\section{REFERENCES:}

1) Kuzucu A, Soysal O, Gunen H. The role of surgery in chest wall tuberculosis. Interact Cardiovasc Thorac Surg. 2004 Mar; 3(1): 99-103. PMid: 17670188.

2) Sama JN, Chida N, Polan RM, Nuzzo J, Page K, Shah M. High proportion of extrapulmonary tuberculosis in a low prevalence setting: a retrospective cohort study. Public Health. 2016 Sep; 138: 101-7. PMid: 27137870. PMCid: PMC5012930.

3) Alavi SM, Salmanzadeh S, Bakhtiyariniya P, Albagi A, Hemmatnia F, Alavi L. Prevalence and treatment outcome of pulmonary and extrapulmonary pediatric tuberculosis in southwestern Iran. Caspian J Intern Med. 2015 Fall; 6(4): 213-9. PMid: 26644895. PMCid: PMC4649270.

4) Yone EW, Kengne AP, Moifo B, Kuaban C. Prevalence and determinants of extrapulmonary involvement in patients with pulmonary tuberculosis in a Sub-Saharan African country: a cross-sectional study. Scand J Infect Dis. 2013 Feb; 45(2): 104-11. doi: 10.3109/00365548.2012.714905. PMid: 22992019.

5) Tatelman M, Drouillard EJ. Tuberculosis of the ribs. Am J Roentgenol Radium Ther Nucl Med. 1953 Dec; 70(6): 923-35. PMid: 13104727.

6) Bloch AB, Rieder HL, Kelly GD, Cauthen GM, Hayden CH, Snider DE, Jr. The epidemiology of tuberculosis in the United States. Implications for diagnosis and treatment. Clin Chest Med. 1989 Sep; 10(3): 297-313. PMid: 2673643.

7) Chang JH, Kim SK, Lee WY. Diagnostic issues in tuberculosis of the ribs with a review of 12 surgically proven cases. Respirology. 1999 Sep; 4(3): 249-53. PMid: 10489667.

8) Chen CH, Shih JF, Wang LS, Perng RP. Tuberculous subcutaneous abscess: an analysis of seven cases. Tuber Lung Dis. 1996 Apr; 77(2): 184-7. PMid: 8762856.

9) Shields TH , Locicero III J , Ponn RB . General thoracic surgery, 5th edition, vol 1, Lippincott Williams \& Wilkins $2000: 563-69$.

10) Carstensen E. [Surgical treatment of chest wall tuberculosis]. Chirurg. 1980 Mar; 51(3): 163-5. PMid: 7398486.

11) Faure E, Souilamas R, Riquet M, Chehab A, Le Pimpec-Barthes F, Manac'h D, et al. Cold abscess of the chest wall: a surgical entity? Ann Thorac Surg. 1998 Oct; 66(4): 1174-8. doi: 10.1016/S00034975(98)00770-X. PMid: 9800802. 
12) Hsu HS, Wang LS, Wu YC, Fahn HJ, Huang MH. Management of primary chest wall tuberculosis. Scand J Thorac Cardiovasc Surg. 1995; 29(3): 119-23. PMid: 8614779.

13) Burke HE. The pathogenesis of certain forms of extrapulmonary tuberculosis; spontaneous cold abscesses of the chest wall and Pott's disease. Am Rev Tuberc. 1950 Jul; 62(1-B): 48-67. PMid: 15425827.

14) Lee G, Im JG, Kim JS, Kang HS, Han MC. Tuberculosis of the ribs: CT appearance. J Comput Assist Tomogr. 1993 May-Jun; 17(3): 363-6. doi: 10.1097/00004728-199305000-00004. PMid: 8491894.

15) Khalil A, Le Breton C, Tassart M, Korzec J, Bigot J, Carette M. Utility of CT scan for the diagnosis of chest wall tuberculosis. Eur Radiol. 1999; 9(8): 1638-42. doi: 10.1007/s003300050900. PMid: 10525881.

16) Morris BS, Maheshwari M, Chalwa A. Chest wall tuberculosis: a review of CT appearances. Br J Radiol. 2004 May; 77(917): 449-57. PMid: 15121713.

17) Blunt SB, Harries MG. Discrete pleural masses without effusion in a young man: an unusual presentation of tuberculosis. Thorax. 1989 May; 44(5): 436-7. PMid: 2763247. PMCid: PMC461857. 